Камского государственного института физической культуры. - 2007. - № 4 (3).

4. Сибилева Е.Н. Транзиторная гипертиреотропинемия у новорожденных в йодобеспеченном районе / Е.Н. Сибилева // Экология человека. - 2004. - № 3. - С. 21-23.

5. Теддер Ю.Р. Состояние здоровья и адаптация первоклассников к обучению в школе в условиях Севера / Ю.Р. Теддер, Т.С. Копосова // Экология человека. - 2000. - № 2. - С. 44-46.

6. Шеплягина Л.А. Состояние когнитивной сферы у детей в районах с дефицитом йода / Л.А. Шеплягина, ІІ.Д. Макулова, О.И. Маслова // Консилиум медикум. - 2001 - № 1. - С. 31-34.

Статья отправлена: 27.03.2017 г.

(C) Борейко А.П.

\title{
ЦИТ: иа117-065
}

DOI: 10.21893/2415-7538.2016-05-1-065

УДК634.37(043.2)

\section{ДЕЙСТВИЕ ФАСОВАННОЙ ВОДЫ НА УРОВЕНЬ БЕЛКОВОГО СИНТЕЗА ПРОСТКОВ АLLIUМ ТЕSТ ПО ДИНАМИКЕ КЛЕТОЧНЫХ МАРКЕРОВ}

Херсонский государственный университет

Sidorovich M.M.

\section{OPERATING OF THE PACKAGED WATER ON LEVEL OF ALBUMINOUS SYNTHESIS OF ALLIUM TEST ON DYNAMICS OF CELLULAR MARKERS}

Kherson state university, Kherson, University 34, 73000

Аннотация. В работе рассматривается иитомониторинг качества фасованной воды в разных микрорайонах города, который проведен методом фитотестирования. Его результаты свидетельствуют о иитотоксичности воды «Бон-Буассон». Она была связана с усилением белкового синтеза в клетках корня Allium test. Сделано предположение о снабжении городского населения подделками воды «Моршинская».

Ключевые слова: фитотестирование, качество фасованной воды, ядрышковый биомаркер.

Abstract. In this paper we describe the cotomonitoring of quality of the packaged water in the different microregions of city. It is conducted by the method of fitotesting. His results testify to the cytotoxicity of water of "Bon-Buasson". She was related to strengthening of albuminous synthesis in the cages of root of Allium test. Supposition is done about providing with of urban population the imitations of water "Morshinska".

Key words: fitotesting, quality of the packaged water, nucleolar biomarker.

Одно из направлений исследования межкафедральной группе по проблемам цитоэкологии ХГУ - изучение качества питьевой воды из системы нецентрализованного водоснабжения города (пунктов продажи). Его 
результаты, полученные на фитотестах, представлены в нескольких публикациях последних лет [6-9]. В научной литературе методом биотестирования интенсивно разрабатывают другой аспект указанной выше проблемы - качество фасованной питьевой воды [1-5]. При помощи батареи биотестов создана даже классификация бутилированных вод Украины, в основу которой положена степень ее питьевой пригодности. Для ее обоснования использовали биометрические [4] и клеточные параметры [5] биотестов. В ней марка «Моршинская» - вода высокого качества, а «Бун-Буассон» занимает одно из последних мест. Однако вопрос о качестве фасованной воды с точки зрения ее подделок остается открытым. Вместе с тем предварительные исследования аптечной воды «Малятко» показали разное значение этого параметра в 0,5 л и 1,5 л емкостях. Поэтому целью данного исследования явилось определение качества фасованной воды марок «Моршинская» и «Бон-Буассон», которыми снабжаются разные микрорайоны г..Херсона, по их влиянию на белковый синтез клеток фитотеста.

Материал и методы исследования. Для оценки качества фасованной питьевой воды семена Allium cepa L. сорта Батун замочили на 1 сутки в 5 вариантах воды (см.табл.1) и прорастили в термостате 4 суток. Для определения цитологических параметров, связанных с синтезом белка в клетке ядрышкового биомаркера $(\boldsymbol{Я \boldsymbol { B }})$ и площади неделящихся клеток $(\boldsymbol{S})$ - кончики корней проростков зафиксировали на 3-и сутки в фиксаторе Кларка в течение 24 часов. Далее их хранили в холодильнике в $70^{\circ}$ спирте. Перед приготовлением давленых препаратов кончики корней перенесли на 1-2 сут в ацетоорсеин. На 3-х препаратах для каждого варианта просмотрели способом сканирования 3000 клеток с ядрами. На них отдельно учли ядра 3 1-м, 2-a, 3-a i 4-a ядрышками. При помощи окуляр-микрометра на этих же препаратах определили площадь 30 неделящихся клеток для каждого варианта воды. Препараты исследовали под микроскопом Micromed при увеличении 960 Полученные данные (объем выборок репрезентативный для $p=0,05$ ) обработали статистически с использованием pecypca Exel и непараметрического $(\lambda)$ критерия.

Результаты исследования. Предварительные исследования динамики биометрических показателей проростков Allium test, которые сформированы на тестируемой воде, показали у всех вариантов наличие отличий качества от эталонного. Для конкретизации и обоснования доказательства токсичности воды в исследовании охарактеризовали изменения цитологических показателей клеток корня проростка $A l$. cepa $L$. Таблица 2 содержит полученные данные значений $\boldsymbol{Я \boldsymbol { Б }}$ и средние значения $\boldsymbol{S}$ вместе с результатами их статистической обработки. Как свидетельствует эта таблица, все варианты воды «Бон-Буассон» достоверно отличались от эталона по значениям двух маркеров: наблюдалось увеличение «многоядрышковости», которое совпадало с ростом размеров неделящихся клеток, т.е вода стимулировала синтез белка. Иную ситуацию продемонстрировала вода «Моршинская»: $\boldsymbol{S}$ не отличалась от эталонной, но у варианта 1 М $\boldsymbol{Я Б}$ указывал на усиление белкового синтеза в клетках фитотеста. Полученные данные о качестве двух марок фасованной воды, которые 
поступают в г. Херсон, не вполне соответствуют литературным данным, о которых речь шла выше [3].

Таблиця 1

Исходные данные фасованной воды разных районов г. Херсона

\begin{tabular}{|c|c|}
\hline Вариант воды, микрорайон г. Херсона & Адрес магазина \\
\hline Еталон (по данным городоканала) & Локальная скважина горводоканала \\
\hline $\begin{array}{l}\mathbf{1 6} \text { «Бон-Буасон» } \\
\text { Центральный р-н }\end{array}$ & ул. Дружбы, магазин «Попелюшка» \\
\hline 2 Б «Бон-Буасон» р-н Остров & ул. Патона, магазин «Продуктовий» \\
\hline $\begin{array}{l}\text { 3Б «Бон-Буасон» } \\
\text { Шуменский р-н }\end{array}$ & ул. Иллича, магазин «Гурман» \\
\hline $\begin{array}{l}\mathbf{1 M} \text { «Моршинская» } \\
\text { Шуменский р-н }\end{array}$ & ул. Иллича, магазин «Гурман» \\
\hline 2М «Моршинская» р-н Остров & ул. Патона, магазин «Продуктовий» \\
\hline
\end{tabular}

Таблиця 2

Значення ядерцевого биомаркера и средней площади клеток корня проростков Allium test, которые сформированы на фасованной воде г. Херсона

\begin{tabular}{|c|c|c|c|c|c|c|}
\hline \multirow{2}{*}{$\begin{array}{c}\text { Вариант } \\
\text { воды }\end{array}$} & \multicolumn{4}{|c|}{ Кількість клітин (\%) 3} & \multirow{2}{*}{$\begin{array}{c}\text { Вариант } \\
\text { воды }\end{array}$} & \multirow{2}{*}{$\begin{array}{c}\text { Площадь } \\
\text { клетки }\end{array}$} \\
\hline & $\begin{array}{c}1-м \\
\text { ядерыш. }\end{array}$ & $\begin{array}{c}2-a \\
\text { ядерыш. }\end{array}$ & $\begin{array}{c}\text { 3-a } \\
\text { ядерыш. }\end{array}$ & $\begin{array}{c}4-a \\
\text { ядерыш. }\end{array}$ & & \\
\hline эталон & 65,7 & 24,8 & 6,7 & 2,8 & эталон & $0,23 \pm 0,05$ \\
\hline $16 *$ & 59,7 & 29,6 & 7,6 & 3,1 & $15 *$ & $0,41 \pm 0,10$ \\
\hline $2 \mathbf{5}^{*}$ & 61,3 & 26,9 & 6,9 & 3,0 & $2 \mathbf{5}^{*}$ & $0,79 \pm 0,07$ \\
\hline 3 Б* & 59,1 & 33,0 & 5,1 & 2,0 & $35^{*}$ & $0,68 \pm 0,08$ \\
\hline $1 M^{*}$ & 58,3 & 34,2 & 7,5 & 2,6 & $1 M^{*}$ & $0,41 \pm 0,10$ \\
\hline $2 M$ & 63,3 & 27,8 & 6,0 & 2,8 & $2 M$ & $0,34 \pm 0,10$ \\
\hline
\end{tabular}

*- достовірно відрізняється від еталону з $p=0,05$

Таким образом, установленное методом фитотестирования отличие качества марки "Моршинская" от качественной воды в сочетании с результатами ее цитомониторинга дает возможность предположить, что в 2. Херсон снабжается ее подделками. Поэтому, невзирая на существование классификации фасованных вод по качеству, необходим контроль этого показателя у марок, которые поступают в торговую сеть города.

Литература

1. Архипчук В.В. Проблеми якості питних бутильованих вод // Хімія і технологія води воды. - 2000. - Т.26. - №4. - С. 403-414.

2. Архипчук В.В. Оцінка якості питних бутильованих вод методами біотестування // Хімія і технологія води. - 2004. - Т. 26. - № 5. - С. 485-525.

3. Гончарук В.В. та інш. Комплексна оцінка якості фасованих вод.// Вісник НАН України. - 2005. - № 3. - С. 47-58.

4. Гончарук В. В. и др.Исследование мутагенности и генотоксичности питьевой воды // Химия и технология воды. - 2013. - Т. 35. - № 5. -- С. 426-435. 
5. Лахіна Д.О. та інш. Визначення якості розливної води м. Херсону засобами фітотестування // Актуальні проблеми природничо-математичної освіти в середній і вищій школі, Херсон, 2014- С.116-119.

6. Сидорович M.M. Використання біометричних показників Allium testдля визначення якості питної води міста// Науковий часопис. Нац. Пе. Ун-ту іиені М.П. Драгоманова. Серія 2-. Біологія. - випуск 5.- 2013. - С.182-192.

7. Сидорович М.М.,Прокопець Л.О. та інш. Експрес-методика визначення нефасованої питної води на основі фітотестування // Природничий альманах. Біологічні науки, випуск 22. Збірник наукових праць. - Херсон: ПП Вишемирский, 2015. - С. 89-95.

8. Сидорович M.M., Кундельчук О.П. и др. Lemna minor L. - фітотест для визначення токсичності і полютантності міської питної води 3 нецентралізованого водопостачання (пунктів продажу) // Научный взгляд в будущее. - Выпуск 2(2). Том.12. - Одесса: КУПРИЕНКО С.В.,2016. - С.80-87.

9. Содоль Г.А., Ружицкая Н.А. Методи біотестування в оцінці якості бутильованих вод // Збірник тез доповідей III науково - практичної конференції «Вода в харчовій промисловості». - Одеса, 2012. - С. 26-27.

\section{ЦИТ: ua117-095}

DOI: 10.21893/2415-7538.2016-05-1-095

УДК $502.7(0.21)$

\section{${ }^{1}$ Виноградов-Салтиков В.О., ${ }^{2}$ Федоров В.Г., Кепко О.І., ${ }^{3}$ Глуздань А.О. ЕКОЛОГІЯ, ЕНЕРГЕТИКА, РЕСУРСОЗБЕРЕЖЕННЯ (ВИЗНАЧЕННЯ, ЗВ'ЯЗОК) \\ ${ }^{1}$ Національний технічний університет Украӥни «Київський політехнічний інститут»

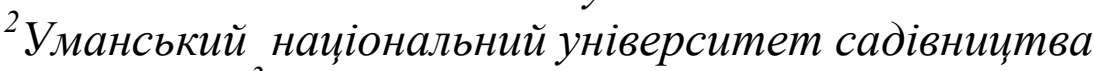 \\ ${ }^{3}$ ТОВ «ВП «Проммашсервіс» \\ ${ }^{1}$ Vynohradov-Saltykov V., ${ }^{2}$ Fedorov V., Kepko O., ${ }^{3}$ Gluzdan A. \\ ENVIRONMENT, ENERGY, RESOURCE (DEFINITION, INTERCONNECTION) \\ ${ }^{1}$ National Technical University of Ukraine "Kyiv Polytechnic Institute" \\ ${ }^{2}$ Uman national university of horticulture \\ ${ }^{3}$ Ltd. "OP "Prommashservis"}

Анотація. Пропонується класифікація різних видів екології, включно із тими, щуо далеко відходять від первинного сенсу назви цієї науки, але які $є$ важливими для України (екологічний туризм, екологічний тероризм тощьо).

Аналізується класифікачія різних енергетичних ресурсів, включаючи поновлювальні, з точки зору відповідності термінології, що закладено в їх сенс. Уточнюються поняття та назви окремих різновидів енергї та галузей енергетики, вводиться новий тип енергї - біогеохімічна, щуо тісно пов'язує екологію з енергетикою. Суттєвий внесок в здобуття енергетичной 